\title{
Correction to: Sustainable development goals assessment of Erzurum province with SWOT-AHP analysis
}

\author{
Çağlar Kıvanç Kaymaz ${ }^{1}$ (D) . Salih Birinci ${ }^{1}$ (D) . Yusuf Kızılkan ${ }^{1}$ (D)
}

Published online: 2 July 2021

(c) Springer Nature B.V. 2021

\section{Correction to: Environment, Development and Sustainability https://doi.org/10.1007/s10668-021-01584-w}

In the original publication of the article [1], the corresponding author has been wrongly identified as Yusuf Kizilkan. Çağlar Kıvanç Kaymaz is the only corresponding author of the article.

The correction has been corrected in the original publication.

Publisher's Note Springer Nature remains neutral with regard to jurisdictional claims in published maps and institutional affiliations.

The original article can be found online at https://doi.org/10.1007/s10668-021-01584-w.

Çă̆lar Kıvanç Kaymaz

ckkaymaz@atauni.edu.tr

Salih Birinci

sbirinci@atauni.edu.tr

Yusuf Kizılkan

yusuf.kizilkan@atauni.edu.tr

1 Department of Geography, Faculty of Letters, Ataturk University, Yakutiye, 25240 Erzurum, Turkey 